\title{
USING TV COMMERCIALS AS AUTHENTIC MATERIALS FOR TEACHING
}

\section{LISTENING}

\author{
Fendik Wahyoe Saputro \\ fendikwahyoes45@gmail.com \\ Sulistyani \\ sulissulistyani@rocketmail.com \\ University of Nusantara PGRI Kediri
}

\begin{abstract}
The use of authentic materials is important in teaching EFL students due to its real life English language usage. For this reason, this article discusses the way how to use TV commercials as an authentic materials in teaching one of the skills in English, that is listening. This article serves several materials, activities, and steps of how we implement the usage of TV commercials as authentic materials to improve listening ablity of the students. These materials, activities and steps is aimed to encourage and to give the real life usage of English, so the students can implement it in their daily communication abroad. These strategies was collected through several articles reading and experts in EFL teaching. It is known that both EFL teachers and students have much to gain from TV commercials. TV commercials have visual, verbal and written images, interesting vocabulary and cultural features, and help students to improve their listening skills and to speak English in a more natural way.
\end{abstract}

Keywords: TV commercials, authentic materials, teaching listening

\section{Introduction}

Television commercials are fun, persuasive, and memorable acts of communication that not only can capture the attention of language learners but also can be used to stimulate them to think critically about deeper linguistic and cultural meanings. As Smith and Rawley (1997) argue that TV commercial is a powerful tool as any politician, industrialist, businessman or communications expert will attest. The literature on TV commercials describes how to use them in language classrooms, the advantages of doing so, and how to find and select them. But until recently, using television commercials was an arduous task because of the difficulty of acquiring them. Before the Internet and TiVo, finding and preparing commercials for classroom use required a great deal of time; today, they are easily obtained in digital format, making their preparation and use easier. With 
| Volume: 1 | Number: 2 | October 2016 | ISSN: 2503 - 4405|

the difficulties of acquiring commercials eliminated, teachers can begin incorporating them into their multilevel or mixed-ability curricula.

As teachers, we know that no matter how carefully a school tries to divide students into different levels of language ability, discrepancies in language learning goals, learning styles, educational backgrounds, and levels of motivation are always present in every classroom. These variations are further aggravated when students of different language proficiency levels coexist in one class. Besides struggling to organize a syllabus so as to achieve a shared set of goals, teachers also have the difficult task of selecting materials that can be used by all students at the same time. TV commercials can aid in satisfying the needs of multilevel or mixed-ability classes because their visual qualities greatly increase students' comprehension, this is in line with Smith and Rawley statements, which the impact of an entertaining commercial is beyond the pedagogical powers and resources of teachers to create. However, that power can be harnessed in the English as a second language (ESL) classroom by using TV commercials to teach both listening and critical thinking skills.

\section{Listening}

According to Basquille, Listening is the activity of paying attention and trying to get the meaning from something that has been listened. While hearing is passive, successful listening is definitely an active skill which requires involvement.

Listening is language skill which needs the most frequently practice in using in everyday life. Morley has estimated that we listen twice as much spoken language as we spoke, four times as much as we read, and five times as much as we write.

According to Rost:

Listening is a process holding a continuum of active passive process, where is the process is under the control of the listener, and passive process. listening means the process where is the listener catch what the speaker has said; to get the speaker's idea; to decode the speaker message; to unpack the speaker's content; to receive the transfer of images, impression, thought, beliefs, attitudes, and emotional from the speaker. 
Nadig states that there are three basic Listening Modes. First, competitive or combative listening happens when listeners are more interested in promoting their own point of view than in understanding or exploring someone else's view on listening. They either listen for openings to take the floor, or for flaws or weak points they can attack. As they pretend to pay attention they are impatiently waiting for an opening, or internally formulating their rebuttal and planning their devastating comeback that will destroy the argument and make them the victor. Second, in passive or attentive listening happened when listeners are genuinely interested in hearing and understanding the other person's point of view. We are attentive and passively listen. We assume that we heard and understand correctly. but stay passive and do not verify it. Finally, active or reflective listening is the single most useful and important listening skill. In active listening learners also genuinely interested in understanding what the other person is thinking, feeling, wanting or what the message means, and we are active in checking out our understanding before we respond with our own new message. We restate or paraphrase our understanding of their message and reflect it back to the sender for verification. This verification or feedback process is what distinguishes active listening and makes it effective.

According to Field (2011), there are standard format for the listening lesson developed. They are divided into three parts. First, pre-listening; teaching at the beginning of the listening lesson. It contains implications of new vocabulary or keywords in the passage. Second is listening. It is divided into two parts; those are extensive listening and intensive listening. Extensive listening is part of the listening process which is followed by general questions establishing context. Intensive listening is part of listening process focused on the student's attention on language form. Third, post listening. It focuses on analysis of the language in the text. The purpose of this part is the ability of language learners to infer the meaning of new words from the context.

From definitions above, the writer conclude that Listening is the act of hearing attentively. Listener gets the information from the speaker, and then can result imagination and understanding. When a person decides to communicate with another person, he or she does so to fulfill the need. The person wants something, feels discomfort, and or has feeling or thoughts about something. In 
| Volume: 1 | Number: 2 | October 2016 | ISSN: 2503 - 4405|

deciding to communicate, the person selects the method or code which he or she believes it will effectively deliver the message, impression, thought, beliefs, attitudes, and emotional to the other person. Effective communication exists between two people when the receiver interprets and understands the sender's message in the same way the sender intended it. The researcher states that the English teacher has to make listening class communicate with giving more chance for students. He/she can link the lesson with students' daily problems and give materials relate on how to solve the problems. It is also good if students can learn moral values from the lesson that will be used in their daily life. The important thing for the teacher is to give the students more opportunity to practice their listening skill by providing more activity that put them into the real practice of communication.

\section{Authentic Materials}

Taylor's article (1994) includes several definitions of authentic materials and texts. Morrow's (1977) says that an authentic material can be defined as "a stretch of real language, produced by a real speaker or writer for a real audience and designed to convey a real message of some sort." Both Wilkins' (1976) and Harmer's (1983) refer to an authentic text (written or spoken) as a text made for native speakers of the language, not for language students. Nunan's (1989), states that an authentic text is "any material which has not specifically been produced for the purposes of language teaching" (quoted in Taylor, 1994, p. 2). In addition, in Toward wider use of literature in ESL: Why and how, Gajdusek (1988, p. 228) defines authentic texts, when referring to stories, as those which are original, not adapted. Moreover, Karpova (1999, p.18) defines authentic materials as "items that normally go into a trash can," such as tea boxes. She explains how the text from tea boxes can be used. Finally, Martinez (2002, p.1) quotes Peacock (1977) on the definition of authentic materials: "Materials that have been produced to fulfill some social purpose in the language community." As teachers can readily understand, authentic texts/materials are produced for the target community, not for language teaching. But, by using them in class, teachers welcome the target culture into their classrooms, making their classes a more natural environment for language learning 


\section{Sample Material}

Level : High intermediate and advanced levels; and lower levels (more time should be allocated for each activity or the commercial selected should be simple enough for this level)

Objective : To help EFL students to express their ideas in English in a natural way, learn about the target culture and become critical thinkers Skills: Listening, speaking, writing and reading; with particular emphasis on listening and speaking

Time : 90-100 minutes (high-intermediate and advanced levels); 135150 minutes (lower levels)

Material : Videotapes or CDs of TV commercials and/or public announcements produced by and for native speakers, and the hardware necessary to work with the videos and/or CDs

\section{Previewing Activities--Focus on the Topic}

Step 1. Previewing activities about what students will see and hear

Students make predictions about what they will see and hear. The teacher encourages students to say anything that comes to mind; that is, they persuade students to take risks. As future professionals, students will be faced with problems requiring fast thinking. This type of activity helps students to train their minds. In many countries, students are passive learners: They are taught just to listen to their teachers. They refuse to take risks. "Helgesen (1993) states, 'Listening isn't and can't be passive,' so our job must be to activate their listening along with speaking, grammar, writing, and reading skill areas" (quoted in Davis, 1995, p.3).

Teachers have two choices in Step 1:

1. They tell students what type of product they will see and the name of the product (Davis, 1995, p.3), and then ask them to get into small groups to discuss the type of target market at which the product is directed. Davis suggests things, such as the "age group, sex of consumers, socioeconomic class . . . [and] the product slogan . .."p.3). Davis' suggestions encourage students to generate ideas. A member of each group writes down the answers to report on them 
| Volume: 1 | Number: 2 | October 2016 | ISSN: 2503 - 4405|

orally or writes them on the board as soon as all groups finish discussing the type of target market. If a member of each group writes the responses on the board, all students, especially the visually-oriented ones, will have the opportunity to see what their peers have thought and compare the responses given by all the groups.

2. They write on the board the name of the product or topic of the commercial students will see and hear without giving any further clues. For example, one of the commercials used by the author was "Robitussin," cough syrup sold over the counter in US drugstores. Since students had never heard of it, they did not know what the product name meant; as a result, they asked yes/no questions about the product to guess what kind of product they would be seeing.

Yes/no questions can be handled in two ways: 1) Students can get together in small groups and one member of the group writes down questions students plan to ask the teacher. 2) Students take turns asking questions that come to mind, making sure that no question is asked more than once. Once students guess what kind of product it is and finish discussing the type of target market, teachers can move to Step 2.

If they do not guess what the product is, teachers can either tell them or allow them to see/hear the commercial. The lack of familiarity with the product makes the activity fun, for each group thinks of a product other than the real one. They get very curious and excited while trying to guess what kind of product the commercial is promoting.

Step 2. Making predictions about words/phrases/sentences and images.

Davis (1995,p.3) suggests that at this time students should make predictions about five words that they think they will hear and five images that they believe they will see in the commercial. Teachers can also ask students to make predictions about phrases and/or sentences that they think they will hear and/or read. One member of each group writes down the predictions to report orally or writes them on the board for discussion and subsequent confirmation.

\section{Viewing Activities--Focus on Language}

Viewing or listening to the commercial

Step 1. Verifying predictions 
| Volume: 1 | Number: 2 | October 2016 | ISSN: 2503 - 4405|

Before students confirm their predictions about the product by watching or listening to the commercial once or twice, teachers "can create some sort of information gap by manipulating ..." [students] (Davis 1995,p.3). This can be done in several different ways:

1. The sound of the TV or computer can be off, so students can only see the commercial.

2. The TV set or computer can be turned around, so students see only the back of the TV or computer. Thus, they will have to concentrate on what they hear.

3. Davis (1995, p.3) suggests that half of the students turn their backs to the TV.

4. The TV or computer screen can be half covered (top, bottom or sides).

5. Davis (1995, p.3) suggests that the TV screen can be covered with construction paper full of holes, so students will see the commercial through the holes.

6. The center of the TV screen can be covered but the edges uncovered. Or the edges can be covered and the center uncovered (Stempleski and Tomalin, 1990, p. 66).

If students only see the commercial, they can verify their predictions about the type of product and target market, and the images that they expected to see. If, on the other hand, they only listen to the commercial, they can verify predictions about the type of product (this may not be possible if the product is not clearly described or defined), the type of target market, and words, phrases or sentences they expected to hear.

If they listen to the commercial message, but they see only a part of the screen, they can still discuss their predictions in groups or with the whole class about what they hear and maybe what they see. If their predictions have been written on the board, it is easy for each group to look at them and explain what led them to make those predictions.

Then the students watch the full, unadulterated TV commercial twice and talk about their predictions, and if they were actually included in the commercial or not.

Step 2. Understanding unknown written and/or spoken vocabulary 
| Volume: 1 | Number: 2 | October 2016 | ISSN: 2503 - 4405|

Now that they have seen and listened to the entire commercial, teachers can ask them to concentrate on the vocabulary. They can ask students what words they do not understand. They can watch the commercial one or two more times, depending on their needs. Then, in groups they make a list of unknown words, and when the list is completed, a member of each group writes the unknown words on the board. At this time, if no one already knows the meaning of the words, the whole class tries to guess their meaning by using contextual clues. If contextual clues do not help them, they can look the words up in a thesaurus or dictionary. If they still do not understand the meaning of the words, the teacher can explain the meaning to them.

Step 3. Transcribing the commercial message

Students listen to the commercial as many times as they find necessary (two to four times is usually sufficient). After they listen to it, they transcribe it individually and then compare their version with those of other members of their group to see how well they understood the commercial. Another way to transcribe the commercial is by dividing the number of sentences and/or phrases among the members of a group. For instance, if a group is made up of four students watching a commercial with four sentences or phrases, each member can write down one sentence or phrase. They must listen very carefully because sometimes it is hard to know when one sentence or phrase ends and another one begins.

Then each group can read their version of the commercial aloud and compare theirs to other groups' or write their version on the board and then compare. If students disagree, they can listen to the message until they get all of the information clearly. They discuss what they think they heard and why they think what they heard is correct. The students justify their choices by using their knowledge of grammar, for example. After watching a commercial about Liquid Dial (a type of liquid soup for washing the hands), the author's students argued about the beginning of a sentence. Some said it began with "The best"; others said it started with "It has." A student insisted he heard "It has" because the sentence ended in "don't"; as in, for example--"It has a refreshing aroma while the other brands don't." If the discussion seems to be going nowhere, the instructor should help the students. 
High-intermediate and advanced students can write the text of most commercial messages by themselves. With lower levels, the teacher can give them a copy of the commercial message with a few blanks for them to complete while listening to it. Teachers must also be sure to choose only commercial messages with few phrases or simple sentences, containing language the students can handle.

Step 4. Describing the commercial

A student pretends that someone who has not seen the commercial has just arrived in class. Or, the teacher can actually ask a student or several students to stay outside until the class gets to this step. One of the students who has seen the commercial describes it, trying to use the five senses, and as many shapes and colors as possible, by talking about these features:

- topic of the commercial,

- type of product being advertised,

- purpose of the commercial,

- people, animals and/or objects used in the commercial,

- spoken or written catchy words or phrases used in the commercial,

- type of target market, etc.

The other students who have seen the commercial, too, listen to the student describing the commercial and then give him/her feedback. The student who has not seen or heard the commercial can ask questions, so he/she can get an accurate idea of the commercial. The commercial can then be played one more time for all students to confirm their interpretations.

\section{Teaching Procedure}

When selecting commercials for class use, it is important to view them with an eye toward several major concerns, which include the elements of language that the teacher wishes to focus on, the interests of the students, and the critical thinking skills that fit the commercial. Commercials that tell stories work well for teaching how to organize information, predict, and identify sequence. Commercials that pose a problem, offer choices, or compare two products are best suited for lessons on making associations, comparing and contrasting, drawing conclusions, 
| Volume: 1 | Number: 2 | October 2016 | ISSN: 2503 - 4405|

evaluating, and making judgments. Commercials can be recorded off air from regular television broadcasts, but teachers need to be aware of the copyright guidelines governing their use. Non-profit educational institutions can videotape off-air, but must use the tapes within 10 school days and erase them after 45 calendar days (Stempleski, 1992; also see Richardson and Scinicariello, 1989 for a thorough discussion of the U. S. "fair use" guidelines for off-air taping).

\section{A Three-Stage Lesson Plan}

The classroom activities presented below were designed for ESL students in an advanced-intermediate listening class in a university-level intensive English program. They are intended to demonstrate the types of activities that a teacher can create for using commercials to teach both listening and critical thinking skills. The TV commercials and activities described are used in the context of a thematic unit on advertising. While these activities are linked to a specific commercial, they should be viewed as a model, or frame, that can be adapted to other suitable commercials. The general format follows a three-stage plan of previewing, viewing, and postviewing activities. When actually presenting a lesson, all three stages are followed for each commercial. However, a different commercial is presented for each stage here in order to highlight a greater number of critical thinking skills.

\section{Stage 1: Previewing}

Previewing activities are intended to prepare students for understanding the commercial. They are designed to activate students' schema, or background knowledge, and create interest in the viewing and postviewing activities that follow. The example presented here is based on a 1991 commercial for Dimmetapp medicine which tells a story. The commercial shows a young boy sick in bed with a cold. Family members (mother, father, grandmother, grandfather, and younger brother) gather in the doorway to his bedroom, and the worried expressions on their faces convey their concern. Some of the family members offer their advice to the boy's mother. With each piece of advice, the sick boy pulls the covers farther and farther over his head. After listening to all the advice, the boy's mother goes to the medicine chest to get the Dimmetapp medicine. In the final scene, the boy is out of bed and happily bouncing a basketball in his room.

Procedures: 
1. To start, show the commercial without sound. Tell students to use the visual aspects of the commercial to gain as much information about the product as possible.

2. Put the following questions on a handout or an overhead transparency. In small groups or as a class, have students answer the questions orally. The critical thinking skill associated with each question/activity is noted in brackets.

A) What kind of product is this? Do you know the name of the product?

(B) Who are the people you see? What are their relationships? [making associations]

(C) How do these people feel? [making associations_facial expressions and feelings]

(D) Retell the story. What happened? [sequencing].

(E) How does the boy get well? [seeing cause and effect; drawing conclusions: He takes the medicine and gets well.]

(F) The boy's grandmother, father, and little brother give his mother advice. How does the boy react to the advice? What advice do you think the grandmother gives? The father? The little brother? [predicting; hypothesizing]

3. Now show the commercial again, this time with sound. Tell students to take notes to help them verify or disprove their predictions. [verifying a hypothesis]

\section{Stage 2: Viewing}

The viewing phase is intended to focus students' attention on some aspect of the commercial relevant to the lesson being conducted: the content, the vocabulary, or a cultural theme, for example. The activities for the viewing stage require students to watch the commercial with a purpose and a task. As with the previewing stage, the particular activities will vary with the commercial being used. The following example is based on a 1992 commercial for M\&Ms (candy) . In the previewing stage for this commercial, students imagine that they have been hired to advertise the product. Working in groups, they sample the product and then create descriptions of the images they want to portray and their target audience. Each group then writes a script for a commercial and videotapes one another's groups performing their commercial. 
Procedures:

In the viewing stage, students first watch the commercials they create and write down what they think the intended images and target audiences are. Next, they watch the professional commercial several times, each time with a different task to perform. First they watch in order to answer the following questions. Again, the critical thinking skills required are in brackets.

1. Who do they want to sell this candy to? [making inferences: students infer the intended audience from the different types of people they see in the commercial: children, teenagers, adults, older people]

2. What is the image they have created? [generalizing, making associations, recognizing cause and effect: students see people dancing, smiling, and having a good time. From this they can associate and generalize that the intended image of the commercial is light-hearted and fun. They also see the cause and effect relationship between eating M \& Ms and being happy_even in the rain.]

3. What images are different from the ones the class created? [students compare and contrast the ideas generated by the class in their own commercials with those in the professional commercial.]

The second task students perform with the M\&Ms commercial is watching and filling in the blanks in a close passage, a script of the song accompanying the commercial. This task focuses them on the vocabulary used in the commercial. In order to be successful, they have to select relevant information and ignore that which is irrelevant.

As they work through exercises in the viewing stage, students always have many questions about what they hear, and what they think they hear. Their questions lead to class discussions providing more listening practice and opportunities to discuss the strategies they find most helpful when listening to authentic language. They are allowed to see the commercial over and over_as many times as they request to complete the task they are working on.

\section{Stage 3: Post-viewing}

The post-viewing stage is intended to engage students in using information from the commercials to evaluate what they have seen, check their comprehension, integrate information, and make judgments as critical consumers. By this point in the lesson, students have seen and heard the commercial many times. They have 
| Volume: 1 | Number: 2 | October 2016 | ISSN: 2503 - 4405|

had opportunities to ask questions regarding vocabulary, pronunciation, structures, and cultural themes.

This last example is based on a 1992 commercial for a Mexican restaurant named "Garcia's." The commercial shows a man and a woman who appear to have come to the restaurant from work. Initially they are stiff and proper, but as they enjoy the food and drinks they become progressively more relaxed. The man removes his tie, the woman's hair becomes disheveled; by the time the check comes, they are laughing and carrying on with abandon. To the accompaniment of lively Mexican music, the narrator says, "Garcia's. A great place to unwind and have a good time. And best of all ... (the waiter places the check on the table) ... this won't spoil your fun".

Procedures:

Students answer the following questions in writing, or orally in either a class discussion or in small groups. Critical thinking skills associated with answering are underlined.

1. What is the advantage of going to this restaurant?

Answering this question is a way of checking comprehension of the commercial in general. It also requires students to integrate the information they have picked up and generalize from it. For example, they have to understand that "And best of all ... your check, sir ... This won't spoil the fun" adds up to Garcia's being an inexpensive restaurant.

2. Do you think this is an effective commercial? Explain your answer. What about the commercial attracts you?

What about the commercial offends you? These questions require students to make judgments, evaluate, and interate information. To answer, students must decide what commercials are intended to do, and whether liking a commercial is the same as its being effective. Students have to discuss these issues together before deciding how they want to answer. Going through this process helps them see that there is never just one answer to questions of this nature.

3. Would this commercial be effective in your country? Explain your answer.

This question requires students to relate information to their own lives and values and make comparisons to the commercials in their countries. To do this, 
| Volume: 1 | Number: 2 | October 2016 | ISSN: 2503 - 4405|

students have to think carefully about the advertising norms and values in their own countries and determine whether and how they differ from those in advertising in the USA. In the past, this comparison has led to students bringing videos of commercials from their countries to class to demonstrate the differences.

\section{Conclusion}

The television commercial has much to offer ESL teachers and students. It's brevity, language redundancies, visual impact, interesting vocabulary, and cultural components combine to provide ESL students opportunities to improve their listening skills. However, for students who must leave their ESL courses and enter the American university classroom, learning to listen and comprehend is not enough. ESL teachers in higher education must help their students learn to listen with discrimination; in addition to understanding a message, students must learn to evaluate what they hear. Television commercials are also an excellent medium for introducing ESL students to the higher-order, critical thinking skills that can increase their chances for academic success in the American educational system. The sample exercises presented here can serve as a frame for designing tasks for the use of other commercials to teach both listening and critical thinking skills in the ESL classroom.

Both EFL teachers and students have much to gain from TV commercials. TV commercials have visual, verbal and written images, interesting vocabulary and cultural features, and help students to improve their listening skills and to speak English in a more natural way. But, that is not all, EFL teachers have an obligation to make it possible for students to take risks because taking risks helps students to train their minds to become fast and critical thinkers. Teachers should not forget that some of their students may continue their education in the US; others may find jobs in the US. However, just by considering their students as future professionals, instructors will understand that critical-thinking skills will help them to communicate their ideas better in both the target and native languages. Wright (2002, p. 258) affirms, "We have to make decisions all the time, and to make reasonable ones, we apply criteria. We can use criteria well or poorly, but we can gain in sophistication in their use through reflective experience and practice." 


\section{References}

Althen,G. (1988). American Ways. Yarmouth, MN.: Intercultural Press, Inc.

Basquille, Andrew, Listening Skills: Improving Learners' Skills with News Reports, taken from http://www.cambridge.org/other files/downloads/esl/booklets/Basquillei mproving-learner's-skill-with-News.pdf

Cohen, J. (1971). Thinking. Chicago, IL: Rand McNally \& Co.

Davis, R. (1994). "Commercial Messages: You Got the Right One, Baby!" TESOL Matters, 4 (6), 10.

Lawrence, K. D. (1987)." The French TV Commercial as a Pedagogical Tool in the Classroom." The French Review. 60, 835_844.

Liontas, J. I. (1991)." Authentic Videos in the Foreign Language Classroom" In L. A. Strasheim (ed.), Focus on the Foreign Language Learner: Priorities and Strategies (pp. 85_98). Lincolnwood, IL: National Textbook Company.

Murcia, Marianne Celce and Elite Olshtain. (2000). Discourse Context in Language teaching, United State: Cambridge University

Nadig, Larry Alan. (2016). Tips on Effective Listening, taken from: http://www.drnadig.com/listening.htm, accessed on January 6th

Richard, Jack C. and Willy A. (2004). Renandya, Methodology in Language Teaching, Cambridge University Press,

Richardson, C. P. \& Scinicariello, S. G. (1989). "Television Technology in the Foreign Language Classroom." In W. F. Smith (ed.), Modern Technology in Foreign Language Education (pp. 43_ 74). Lincolnwood, IL: National Textbook Company.

Rost, Michael, (2002). Teaching and researching listening, Great Britain: personal education limited

Stempleski, S. (1992). "Teaching Communication Skills with Authentic Video." In S. Stempleski \& P. Arcario (eds.), Video in Second Language Teaching: Using, Selecting and Producing Video for the Classroom. Washington, D. C.: Teachers of English to Speakers of Other Languages 